\title{
Industry 4.0: The Digital German Ideology
}

\section{Christian Fuchs}

\section{University of Westminster}

Abstract: Especially in Germany, a vivid public debate about "industry 4.0" has developed in recent years. It advances the argument that industry 4.0 is the fourth industrial revolution that follows on from technological revolutions brought about by water and steam power (industrial revolution 1.0), electric power (industrial revolution 2.0), and computing/computerised automation (industrial revolution 3.0). In 1845/46, Marx and Engels wrote The German Ideology. 170 years later, we live in the time of digital capitalism that has its own peculiar forms of ideology. This paper argues that "industry 4.0 " is the new German ideology, the digital German ideology.

Keywords: Industry 4.0, Industrie 4.0, Germany, German ideology, German digital ideology, Karl Marx

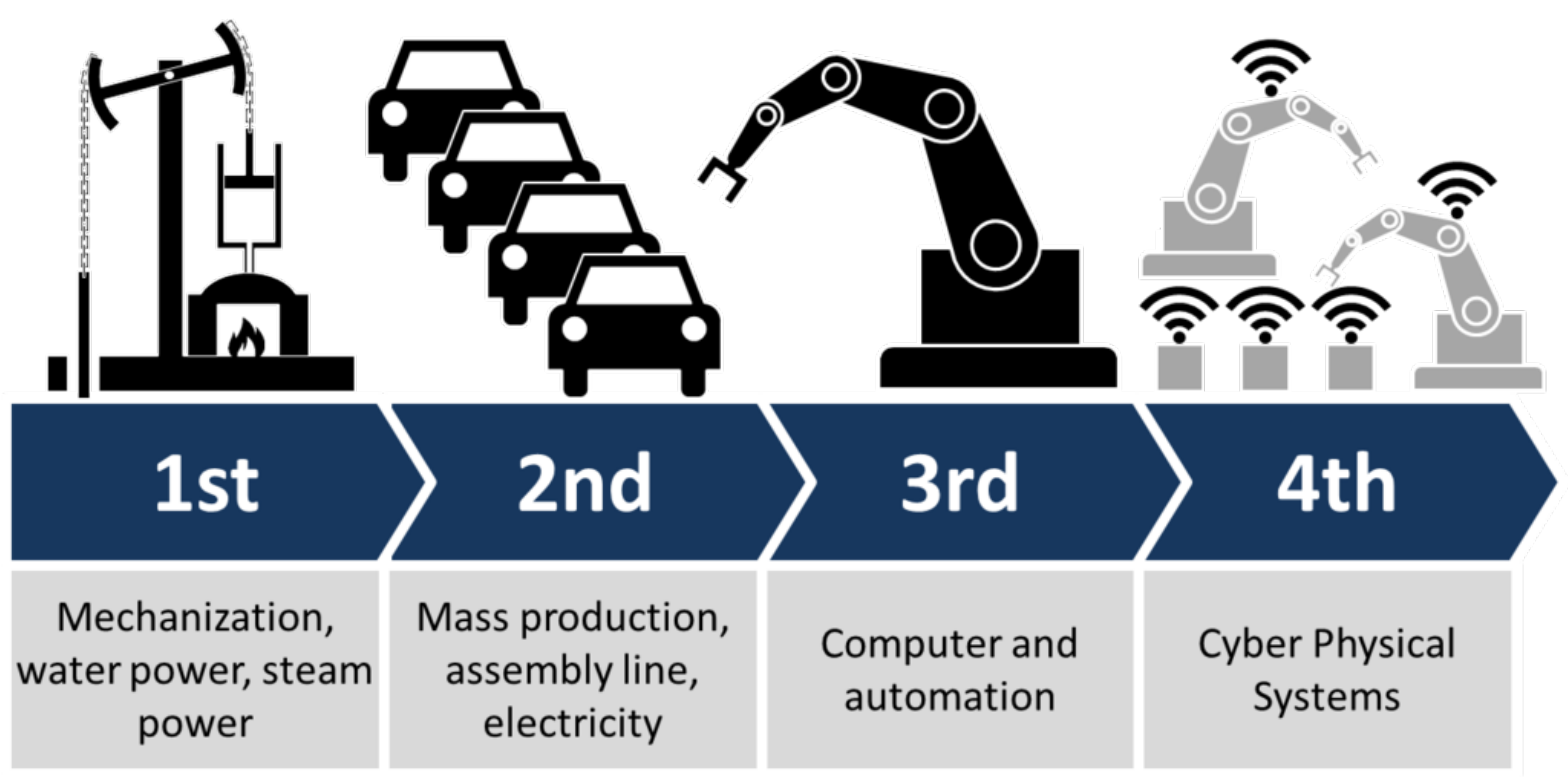

By ChristophRoser, AllAboutLean.com, CC BY-SA 4.0, via Wikimedia Commons

\section{What Is Industry 4.0?}

In the past five years, there has been much talk in the world of digital media about "industry 4.0" and the "industrial Internet" as constituting the fourth industrial revolution. Especially in Germany, a vivid public debate has emerged about "Industrie 4.0" that has featured government strategies and investments, white papers, reports, studies, the formation of an industry interest group (Plattform Industrie 4.0, see http://www.plattform-i40.de), public debates, research projects, a multitude of publications, etc. (see for example: Aichholzer et al. 2015; Austrian Institute of Technology, WIFO \& Fraunhofer Austria Research 2017; Bitkom 2015, Bundesminsterium für Arbeit und Soziales 2015, Bundesministerium für Bildung und Forschung 2013, Bundesministerium für Wirtschaft und Energie 2015; Forschungsunion Wirtschaft - Wis- 
senschaft \& Deutsche Akademie der Technikwissenschaften 2013; Holtgrewe, Riesenecker-Caba \& Flecker 2015; Spath et al. 2013) German corporations involved in industry 4.0 include SAP, Siemens, Software AG, Wincor Nixdorf, Psipenta, Seeburger, CA, Bosch, Felten AG, KUKA, and Festo AG.

What is industry 4.0 ? It is a concept that propagates the combination of the Internet of Things, big data, social media, cloud computing, sensors, Artificial Intelligence, robotics, and the application of the combination of these technologies to the production, distribution and use of physical goods. Cyber-physical systems are embedded computing systems that are applied to industrially produced components: Chips are embedded into manufactured goods so that they can be networked and connected to the Internet. The networking of humans through social media and the generation of big data is extended to machines so that networks of communicating machines are created. In the most extreme case, industry 4.0 means that a good is fully automatically produced, delivered, used, repaired and recycled without human intervention through the networking of different technologies over the Internet. The German Federal Ministry of Education and Research argues that in Industry 4.0, "equipment, machines and single components continuously exchange information" so that "in the future many processes will be controlled and coordinated in real time over large distances" (Bundesministerium für Bildung und Forschung 2013, 6). The result are smart factories and smart products.

\section{The Fourth Industrial Revolution as New Ideology}

The argument advanced by the mainstream debate goes that industry 4.0 is the fourth industrial revolution that follows on from technological revolutions brought about by water and steam power (industrial revolution 1.0), electric power (industrial revolution 2.0), and computing/computerised automation (industrial revolution 3.0). One should always be sceptical about claims that revolutions will inevitably take place soon. So for example, a study by the Fraunhofer Institue for Industrial Engineering claims that "the fourth industrial revolution will have revolutionary impacts on production in Germany" (Spath et al. 2013, 134). Such claims are not just technological determinist (technology is seen as determining economic development) and ignore aspects of class struggle and political economic development, but also proclaim a revolution before it has taken place. The idea of a technological revolution comes in this version before actual technological and economic developments. Industry 4.0 is the attempt to talk a new technological paradigm ideologically into existence.

Industry 4.0 is an ideology that promises economic growth: The German Federal Ministry for Economic Affairs and Energy estimates that within a ten-year period there is a market potential of industry 4.0 technologies (Internet of Things, digital intelligence, robotics, cloud computing) in Germany of almost 45 trillion Euros (Bundesministerium für Wirtschaft und Energie 2015, 8). The figure is based on surveys. It neither takes into account investment and maintenance costs that reduce actual profits nor that industry representatives tend to use surveys as marketing tool and therefore tend to overestimate potential positive economic effects.

\section{The Political Economy Background of the Industry 4.0-Ideology}

Why is there so much talk about industry 4.0 now? And why in Germany? In the USA, the share of manufacturing in value-added decreased from $23.3 \%$ in 1970 to $12.3 \%$ in 2015 . In the UK, there was a decrease from $27.0 \%$ to $9.8 \%$. In Germany, manufacturing's share of value-added is in contrast almost $25 \%$, whereas the share of the FIRE-sector and information and communication-industries is significantly low- 
er than in the USA and the UK (see table 1). Germany has a somewhat less financialised and significantly more manufacturing-based economy than the USA and the UK. Given that Germany and Europe simply cannot compete with the US Internet economy, German industry's goal is to become the capitalist leader and innovator in respect to a different kind of digital technology that makes use of the country's competitive advantage in the export-oriented manufacturing of cars, machinery, chemical and pharmaceutical products, electrical equipment, metals, plastics and rubber products. As part of the Lisbon Strategy, the EU tried to catch up and overtake the USA's world leadership in the development of digital technologies until 2010. This strategy failed. Germany now takes a different approach and wants to digitise and network its manufacturing in order to compete with digital giants such as Google.

\begin{tabular}{|c|c|c|c|}
\hline Industry: & USA & UK & Germany \\
\hline Agriculture, forestry and fishery & $1.1 \%$ & $0.7 \%$ & $0.6 \%$ \\
\hline Manufacturing & $12.3 \%$ & $9.8 \%$ & $23.1 \%$ \\
\hline Construction & $4.2 \%$ & $6.2 \%$ & $4.6 \%$ \\
\hline Information and communication & $6.1 \%$ & $6.5 \%$ & $4.7 \%$ \\
\hline Finance and insurance & $7.3 \%$ & $7.2 \%$ & $4.1 \%$ \\
\hline Real estate & $12.5 \%$ & $13.0 \%$ & $10.9 \%$ \\
\hline FIRE & $19.7 \%$ & $20.2 \%$ & $15.0 \%$ \\
\hline Services & $78.9 \%$ & $79.9 \%$ & $68.9 \%$ \\
\hline
\end{tabular}

Table 1: Share of specific industries in total value added (year 2015), in \%, data source: OECD STAN

In the past decades, neoliberal governments, economists, managers, intellectuals and consultants have celebrated the information and communication sector (consisting of industries such as publishing, broadcasting, telecommunications, software and IT services) as the key growth sector. But in Germany (as in other countries), this sector's share of the economy's total value-added has only increased from $3.5 \%$ in 1991 to $4.7 \%$ in 2015 (see table 2). Hopes for a new regime of capital accumulation are therefore now shifting from the production of intangible digital information to the production of physical products that have embedded chips and therefore blur the boundary between digital and physical systems.

The German manufacturing sector's share in total wages was in $201525.0 \%$, whereas its share in total profits was just $19.6 \%$ (table 2). This is an indication that overall manufacturing labour is rather expensive, which puts limits on profitability. At the same time, labour productivity per hour worked has significantly increased since the early 1990s. The Monetary Expression of Labour Time (MELT) measures the relationship of total value in monetary units and total working hours. It is a measure of labour productivity, the total value produced per hour, where total value includes newly created value and transferred value. MELT combines two measures of value money and labour-time. In German manufacturing, MELT increased from 25.9 Euros per hour in 1991 to 59.6 Euros per hour in 2016 (source of all data used for the calculations presented in this paragraph: OECD STAN). The total number of hours worked in manufacturing decreased during the same period from 15.2 billion hours to 10.9 billion hours, which meant a reduction of the manufacturing share in total annual working hours in the entire economy from $27.4 \%$ to $22.9 \%$. German manufacturing has over a period of 25 years multiplied its productivity by a factor of 2.5 (MELT). The total German economy's MELT increased from 23.8 Euros in 1991 to 47.8 Euros in 2016. This means that manufacturing's productivity increase has in Germany been 
significantly higher than the general productivity increase. At the same time, labour compensation as share of total manufacturing value (the wage share in the manufacturing sector) has in 2016 been $60.8 \%$ in manufacturing in comparison to a wage share of $56.4 \%$ in the total German economy. German manufacturing labour is highly productive and relatively expensive in relation to the total German economy. German capital seems to hope that advancing automation through industry 4.0 technologies will reduce labour costs so that manufacturing profits will in the future make up a higher share of the monetary value produced per hour than they do at the moment. But the big unknown is whether advancing industry 4.0 will not increase fixed constant capital costs (the costs for buying and maintaining digital machines), which could have negative effects on the profit rate if wage costs are not drastically reduced. For German industry, industry 4.0 certainly seems to be the attempt to increase its profits by disempowering and automating manufacturing labour.

\begin{tabular}{|c|c|c|c|c|c|c|c|c|}
\hline Industry: & $\mathrm{V} 1991$ & $\mathrm{~V} 2015$ & $\mathrm{p} 1991$ & $\mathrm{p} \mathrm{2015}$ & $\mathrm{I} 1991$ & $\mathrm{I} 2015$ & $\mathrm{c} 1991$ & $\mathrm{c} 2015$ \\
\hline $\begin{array}{c}\text { Agriculture, Forestry } \\
\text { \& Fishing }\end{array}$ & $1.2 \%$ & $0.6 \%$ & $1.8 \%$ & $0.7 \%$ & $0.9 \%$ & $0.5 \%$ & $1.7 \%$ & $1.5 \%$ \\
\hline Manufacturing & $27.4 \%$ & $23.1 \%$ & $19.6 \%$ & $20.3 \%$ & $30.7 \%$ & $25.0 \%$ & $22.1 \%$ & $19.0 \%$ \\
\hline Construction & $6.0 \%$ & $4.6 \%$ & $4.4 \%$ & $6.4 \%$ & $7.7 \%$ & $5.0 \%$ & $2.0 \%$ & $1.1 \%$ \\
\hline FIRE & $13.4 \%$ & $15.0 \%$ & $26.0 \%$ & $24.7 \%$ & $5.5 \%$ & $5.3 \%$ & $27.9 \%$ & $32.1 \%$ \\
\hline Services & $61.9 \%$ & $68.9 \%$ & $71.3 \%$ & $69.5 \%$ & $57.3 \%$ & $67.4 \%$ & $67.5 \%$ & $74.3 \%$ \\
\hline $\begin{array}{c}\text { Information \& Com- } \\
\text { munication }\end{array}$ & $3.5 \%$ & $4.7 \%$ & $3.4 \%$ & $5.8 \%$ & $3.1 \%$ & $4.4 \%$ & $4.8 \%$ & $4.2 \%$ \\
\hline $\begin{array}{c}\text { ICT-Manufacturing \& } \\
\text { ICT-Services }\end{array}$ & $4.4 \%$ & $5.0 \%$ & $4.0 \%$ & $5.5 \%$ & $3.8 \%$ & $4.8 \%$ & $6.0 \%$ & $4.8 \%$ \\
\hline
\end{tabular}

Table 2: Share of specific German industries in total value-added $(V)$, total profit $(p)$, total labour costs (I), total newly invested constant capital (c), in \%, Data source: OECD STAN

Since the start of the new world economic crisis in 2008, German capitalism's general profit rate (the relationship of profits to investments in the total economy) has decreased from $27.4 \%$ in 2008 to $24.3 \%$ in 2016 (calculation based on data from OECD STAN). Whereas the profit rate in the information and communication sector tends to be well above the general profit rate, the German manufacturing sector's profit rate tends to be well below the general profit rate (see figure 1). Given that in Germany the traditional ICT sector's profit rate is high but its overall share of the economy low, it does not yield enough potential for the large-scale accumulation of capital. The German manufacturing sectors has a much larger absolute size than the ICT sector, but a low profit rate. Industry 4.0 is an expression of German capital interests' strategic hope that the digital sector's high profit rate can be transferred to the manufacturing sector and that thereby the general profit rate's fall and squeeze can be overcome. 


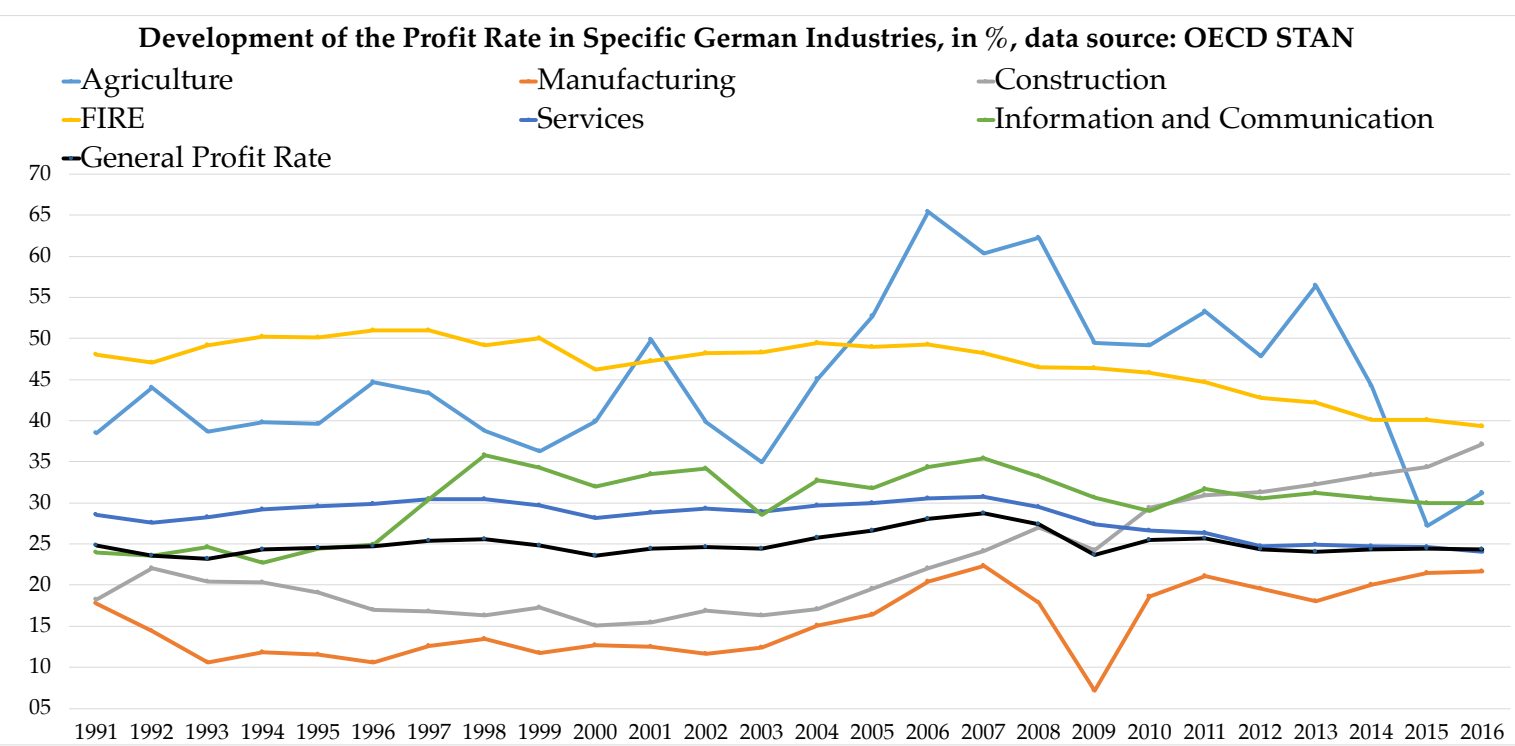

Figure 1: The development of the profit rate in Germany

\section{Ten Reasons Why One Should Be Sceptical of Industry $4.0^{1}$}

First, the complex relations of de-industrialisation and re-industrialisation, technological unemployment and the creation of new jobs is unlikely to develop in a positive direction under the conditions of capital accumulation and capitalism's inherent structural crisis potentials. Automation is a contradictory process, whose effects are not pre-determined, but shaped by the outcomes of class struggles. There is no doubt that the humanisation of work should involve the automation of dehumanising types of labour, such as the labour of warehouse workers, food packers, toilet cleaners, garbage collectors, electronics and textile assembly line manufacturers and in general any hazardous and monotonous labour. But given the capitalist imperative to increase profit, there is capital's material interest to reduce labour costs and make humans a controllable cog in a (digital) machine, so that the most likely outcome of industry 4.0-based automation under capitalist conditions are an increase of technologically-induced unemployment and the human loss of control over the means of production so that digital machines act as means by which capital controls and monitors workers and tries to limit labour's autonomy and decision-power in the production process. Robots do not dissent, do not make claim wage increases and better working conditions, do not go on strike, and do not work to rule, which makes them interesting for capital as a means to limit the potentials for working class struggles.

The humanisation of labour requires struggles for the autonomy of labour from capital, which must include the control and shaping of digital machines and digital automation. Capital and labour bring opposed interests to the process of automation: Capital wants to reduce labour costs and maximise profits, whereas labour has the interest to maximise the universal and collective control of wealth and production, to minimise toil and realise a good life for all. Digital automation faces in capitalism an antagonism between profit interests and human interests.

It is a standard claim in industry and policy reports about industry 4.0 that robots, algorithms and other digital machines should not control and replace, but assist, re-

${ }^{1}$ Critical reflections on and analyses of industry 4.0 include for example: Brödner (2015), Butollo \& Engel (2015), Dörre (2016, 2015), Hirsch-Kreinsen \& ten Hompel (2016), Igelsböck et al. (2016), Pfeiffer (2017), Pfeiffer \& Suphan (2015). 
lieve and complement human work. But if this idea becomes reality or not is not an abstract idealist question, but one that is embedded into the economy's material interests and struggles. The German manufacturing sector accounted in 2015 for $25.0 \%$ of all labour costs, but only for $20.3 \%$ of all profits (see table 2). German manufacturing is relatively labour-intensive: Whereas the general wage share (the share of wages in value-added) was $56.4 \%$ in the total German economy in 2016, it was $60.8 \%$ in the manufacturing industry, a value that was higher than in agriculture (45.6\%), construction (58.5\%), FIRE (20.1\%), services $(55.6 \%)$, and the information and communication sector (53.2\%) (calculation based on data from OECD STAN). Given that total wage costs and labour intensity are relatively high in German manufacturing, there is a material interest that German capital tries to use industry 4.0technologies for replacing human labour and reducing its role in the production process. Because of human labour capacity's complexity, doubts have been raised if it will at all be possible to replace labour in manufacturing to a significant degree by industry 4.0-technologies (Pfeiffer \& Suphan 2015). But one should have no doubt that capital's material interest in reducing labour costs in order to increase profits also shapes the introduction of the newest manufacturing technologies. Industry 4.0 is the newest attempt of class struggle from above in the realm of technology.

Second, if production and produced goods become networked over the Internet and embedded into big data flows, then many issues over privacy, data protection and the surveillance of workers and consumers arise. Capital tries to better control workers and consumers via smart technologies and smart goods. Third, new risks and complex ethical questions arise: Technological systems are not faultless. Complex technological systems create potentials for accidents and disasters. The less humans are in control, the more difficult it is to avoid disasters in crisis situations. If a self-driving bus that navigates via Google Maps causes an accident with 100 casualties, who is prosecuted? The bus manufacturer? Google? The association that leased the bus for organising an excursion of its members? The failing algorithm? Nobody?

Fourth, if humans are increasingly supported by smart digital machines, then new forms of alienation may emerge: You cannot have a meaningful conversation about life with a robot as you can have with a colleague at work. The behaviour of Artificial Intelligence systems is to a certain degree unpredictable, which can cause frustration for workers if they cannot achieve their aims by purposive action because a machine makes them act differently in the same type of work situation on different occasions. Such situations can easily occur when smart machines are used because they calculate and oversee numerous context variables that are not visible to and experienceable by the worker.

The next phase of computing requires massive investments that can only be made by large corporations. Therefore, a fifth impact can be the advancement of capital concentration and monopolisation. Sixth, given that robots can work twentyfour hours, but need at least supervision, questions about working time and work-lifebalance for humans working with robots arise. Seventh, if industry 4.0 is practiced as an attempt to de-globalise and bring outsourced production from developing countries back to capitalist core countries, then issues of de-industrialisation may very well affect the Global South and as a consequence global inequalities could further increase.

The total number of the world's employees in the industrial sector has increased from 550 million in 1991 to almost 800 million in 2017 (see table 3). Taken together, the number of industrial workers decreased in the developed world during that period 
from 187 million in 1991 to 160 million in 2017. In the developing world, the number increased from 369 million to 636 million during the same period. Notably, there was an increase from 51.6 million to 125.2 million in India and from 176.2 million to 208.9 million in China. If one the goals of industry 4.0 is to increase the range of goods manufactured and assembled in Germany and other Western countries, then this could result in de-industrialisation and a loss of industrial jobs in the Global South. The iPad would then no longer be assembled by young, low-paid rural migrants in Chinese Foxconn factories in Shenzen, but by a robot in Munich. For Chinese workers, that would mean downward class mobility from highly exploited industrial workers to becoming unemployed.

\begin{tabular}{|c|c|c|}
\hline Region: & $\mathbf{1 9 9 1}$ & $\mathbf{2 0 1 6}$ \\
\hline Eastern Europe & 57.9 & 45.1 \\
\hline USA & 60.9 & 48.1 \\
\hline Canada & 31.9 & 31.6 \\
\hline Australia \& New Zealand & 3.4 & 4.1 \\
\hline Japan & 2.4 & 3.2 \\
\hline South Korea & 22.6 & 17.3 \\
\hline Singapore & 7.1 & 6.8 \\
\hline UAE & 0.5 & 0.5 \\
\hline Total developed world: & 0.3 & 2.8 \\
\hline Arab states (without UAE) & 187.0 & 159.5 \\
\hline Northern Africa & 3.9 & 12,1 \\
\hline Sub-Saharan Africa & 9.5 & 19.9 \\
\hline Central and Western Asia & 16.9 & 46.1 \\
\hline South-Eastern Asia and the Pacific & 11.3 & 20.1 \\
\hline Lustralia, New Zealand and Singapore) & 28.6 & 72.4 \\
\hline (without Aatin America and the Caribbean \& Mexico & 45.5 & 79.6 \\
\hline Southern Asia & 68.9 & 169.2 \\
\hline Eastern Asia (without Japan and South Korea) & 183,6 & 216,7 \\
\hline Total developing world: & 368.2 & $\mathbf{6 3 6 . 1}$ \\
\hline
\end{tabular}

Table 3: The development of industrial employment in specific world regions, in million, 1991 \& 2016, data source: International Labour Organization, World Employment Social Outlook, http://www.ilo.org/wesodata

Eighth, given that personal transport is one of the main application areas of industry 4.0 (self-driving cars) and fossil fuel continues to be the main energy source of private transport, it is likely that under the regime of fossil capitalism industry 4.0 exacerbates negative environmental impacts. Ninth, if the production of physical and other goods becomes networked over the Internet, then new security threats emerge in the context of industrial espionage, hacking, cyber-crime and cyber-terrorism.

Tenth, last but not least, the role of technology in capitalism's crisis tendencies should not be underestimated. In the past decades, the introduction of computerisation has increased fixed capital costs, which in many countries has negatively impacted profit rates, so that capital has advanced wage repression as attempted counter-measure to the tendency of the profit rate to fall. High-tech digital machines are expensive. If this trend continues, then we can expect a new round of attempts to suppress the wage share (the share of the wage sum in the gross domestic product) 
in order to counter falling profit rates in the context of industry 4.0. Technological hypes have often proven to be mere ideologies that aim at mobilising investments into certain economic sectors, but underestimate capitalism's crisis tendencies. So for example the first Internet boom in the mid-1990s resulted in the dot-com crisis 2000 and the collapse of many Internet corporations. There is much talk about the economic growth potentials of industry 4.0 technologies, but hardly any talk about the impacts on fixed capital costs.

\section{Why Not Schumpeter, but Marx is the Theorist of the Digital Age}

Joseph Schumpeter and his theory of long waves are the best ideological friends of the proponents of industry 4.0. They assume with Schumpeter that new technologies have to bring about a new long wave of economic development. But Schumpeter is haunted by Karl Marx's spectre. In 1845/46, Karl Marx and Friedrich Engels wrote The German Ideology, in which they criticised some of the main German philosophers of their time, such as Ludwig Feuerbach, Bruno Bauer and Max Stirner, for the neglect of capitalism. "It has not occurred to any one of these philosophers to inquire into the connection of German philosophy with German reality, the relation of their criticism to their own material surroundings" (Marx and Engels 1845/46, 30).

170 years later, we live in the time of digital capitalism that has created its own peculiar forms of ideology. Industry 4.0 is the new German ideology, the German digital ideology. It has not occurred to any of the consultants and ideologues of industry 4.0 to inquire into the connection of German ideas with German reality, the relation of their ideology to their own material surroundings. They propagate industry 4.0 as the new capitalist panacea, a digital version of God that is said to solve all economic (and other) problems. The actual contradictory class structure of capitalism and its diverging interests are thereby ignored. The German Ideology continues by saying that "the phantoms formed in the human brain are also, necessarily, sublimates of their material life-process, which is empirically verifiable and bound to material premises" (Marx and Engels 1845/46, 36). Industry 4.0 is an ideological phantom formed in the contemporary bourgeoisie's collective brain. It aims at advancing new forms of accumulation, control and class struggle from above.

Marx and Engels argue that whereas German ideology "descends from heaven to earth, here we ascend from earth to heaven", its critique ascends "from earth to heaven" by setting out from "real, active" humans "on the basis of their real lifeprocess" (Marx and Engels 1845/46, 36). The real life-process of so many today is shaped by precarious labour, social insecurity, and inequalities between the rich and the rest. Capitalism is the struggle between capital and humanity. In digital capitalism, capital aims to appropriate digital machines as instruments for political control, economic accumulation, and ideological manipulation. Social struggle in digital capitalism is one over the control and shaping of digital machines. Only if humanity appropriates fixed digital capital, turns it and sublates it into a means for the end of humanist socialism and socialist humanism, can we be confident that digital technologies will become disentangled from fetishist and ideological forms (such as industry 4.0) and serve humanity as a whole. "For real wealth is the developed productive power of all individuals. The measure of wealth is then not any longer, in any way, labour time, but rather disposable time. [...] Just as in the case of an individual, the multiplicity [Allseitigkeit] of its [society's] development, its enjoyment and its activity depends on economization of time. Economy of time, to this all economy ultimately reduces itself" (Marx 1857/58, 708, 172-173). 


\section{References}

Aichholzer, Georg et al. 2015. Industrie 4.0. Foresight \& Technkfolgenabschätzung zur gesellschaftlichen Dimension der nächsten industriellen Revolution. Zusammenfassender Endbericht. Wien: Österreichische Akademie der Wissenschaften.

Austrian Institute of Technology, WIFO \& Fraunhofer Austria Research. 2017. Beschäftigung und Industrie 4.0. Wien: Bundesministerium für Verkehr, Innovation und Technologie.

Bitkom. 2015. Umsetzungsstrategie Industrie 4.0. Ergebnisbericht der Plattform Industrie 4.0. Berlin: Bitkom.

Brödner, Peter. 2015. Industrie 4.0 und Big Data. Kritik einer technikzentrierten Perspektive. Z - Zeitschrift Marxistische Erneuerung 103: 75-84.

Bundesminsterium für Arbeit und Soziales. 2015. Grünbuch Arbeiten 4.0. Berlin: Bundesminsterium für Arbeit und Soziale

Bundesministerium für Bildung und Forschung. 2013. Zukunftsbild „Industrie 4.0“. Bonn: Bundesministerium für Bildung und Forschung.

Bundesministerium für Wirtschaft und Energie. 2015. Industrie 4.0. Volks- und betriebswirtschaftliche Faktoren für den Standort Deutschland. Eine Studie im Rahmen der Begleitforschung zum Technologieproramm AUTONOMIK für Industrie 4.0. Berlin: Bundesministerium für Wirtschaft und Energie.

Butollo, Florian and Thomas Engel. 2015. Industrie 4.0 - arbeits- und gesellschaftspolitische Perspektiven. Z - Zeitschrift Marxistische Erneuerung 103: 29-41.

Dörre, Klaus. 2016. Industrie 4.0 - Neue Prosperität oder Vertiefung gesellschaftlicher Spaltungen? DFG-Kollegforscherlnnengruppe Postwachstumsgesellschaften Working Paper 02/2016. Jena: Universität Jena.

Dörre, Klaus. 2015. Digitalisierung - Neue Prosperität oder Vertiefung gesellschaftlicher Spaltungen? In Digitalisierung industrieller Arbeit: Die Vision Industrie 4.0 und ihre sozialen Herausforderungen, ed. Hartmut Hirsch-Kreinsen, Peter Ittermann and Jonathan Niehaus, 269-284. Baden-Baden: Nomos.

Forschungsunion Wirtschaft - Wissenschaft \& Deutsche Akademie der Technikwissenschaften. 2013. Umsetzungsempfehlungen für das Zukunftsprojekt Industrie 4.0. Frankfurt am Main: Plattform Industrie 4.0.

Hirsch-Kreinsen, Hartmut and Michael ten Hompel. 2016. Digitalisierung industrieller Arbeit. Entwicklungsperspektiven und Gestaltungsansätze. In Handbuch Industrie 4.0: Produktion, Automatisierung und Logistik, ed. Birgit Vogel-Heuser, Thomas Bauernhansel Michael ten Hompel, 1-20. Berlin: Springer.

Holtgrewe, Ursula, Thomas Riesenecker-Caba and Jörg Flecker. 2015. „Industrie 4.0“ - eine arbeitssoziologische Einschätzung. Endbericht für die AK Wien. Wien: FORBA.

Igelsböck, Judith et al. 2016. Bestandsaufnahme Arbeitspolitik in Oberösterreich: Herausforderungen und Perspektiven im Kontext von Industrie 4.0 und veränderten Marktanforderungen. Linz: Institut für Arbeitsforschung und Arbeitspolitik an der Johannes Kepler Universität Linz.

Marx, Karl. 1857/58. Grundrisse. London: Penguin.

Marx, Karl and Friedrich Engels. 1845/46. The German Ideology. In MECW Volume 5, 19539. London: Lawrence \& Wishart.

Pfeiffer, Sabine. 2017. The Vision of "Industrie 4.0" in the Making - a Case of Future Told, Tamed, and Traded. Naonoethics 11: 107-121.

Pfeiffer, Sabine and Anne Suphan. 2015. Der AV-Index. Lebendiges Arbeitsvermögen und Erfahrung als Ressourcen auf dem Weg zu Industrie 4.0. Universität Hohenheim Lehrstuhl für Soziologie Working Paper 2015/1. Hohenheim: Universität Hohenheim.

Spath, Dieter et al. 2013. Produktionsarbeit der Zukunft - Industrie 4.0. Stuttgart: Fraunhofer Verlag. 


\section{About the Author}

Christian Fuchs

is co-editor of tripleC: Communication, Capitalism \& Critique (http://www.triple-c.at). http://fuchs.uti.at 